\title{
Using "plasma TV" broadcasts in Ethiopian secondary schools: A brief survey
}

\author{
Getnet Demissie Bitew \\ The University of Melbourne
}

\begin{abstract}
The objective for this study is to investigate the contribution of the "plasma" mode of instruction to the school experiences of students in Government secondary schools in Ethiopia, as viewed by students, their parents and teachers, and by comparing it with experiences in Catholic secondary schools, which did not use "plasma". Interviews, observations and document analyses were used as data collection instruments. It was observed that Government and Catholic Schools use the same national curriculum but employ different classroom practices. Government schools were using a live, nationally broadcasted "plasma" television mode of instruction, whilst the Catholic schools used traditional face to face methods of teaching. However, the two groups of participants; students, teachers and parents in the two schools, have different comments on the actual teaching-learning practices of the schools irrespective of their own classroom experiences. Recommendations based on the data are presented.
\end{abstract}

\section{Background to the study}

Students' formal learning in schools is a cumulative effect of all the experiences they acquire in the school environment. What the students do in the school; what they acquire in the form of knowledge and skills; what they develop in the form of thinking, attitudes and habits through their formal, as well as informal interactions with the school members, inside and outside of the classrooms, all play crucial roles in the students' life. Specifically, the curriculum materials which the students learn in the school and the methodology underpinning in it are the foremost factors, mentioned by many researchers (e.g. Berumen, 2004; Cauley, Certo \& Chafin, 2003), effecting the students' school experience. The implication of this assertion is that the provision of different curriculum materials and/or the use of different ways of learning for two groups of students can result in differences in the students' school experiences.

In this respect, Government and Catholic Schools of Ethiopia use the same national curriculum but employ different classroom practices. Government schools have used a live, nationally broadcasted "plasma" mode of instruction for 35 minutes of the 45 minutes assigned for each lesson period, since the end of 2004. It is an e-learning video broadcast over Internet protocol networks to wide plasma television screens installed in each classroom, via a satellite receiving device named Plasma Display Panels (PDPs). The Catholic schools do not use the "plasma" transmission, instead using traditional face to face methods of teaching. Thus, this paper is aimed at investigating the effects of the "plasma" mode of instruction upon the actual school experiences of students in the Government secondary schools, comparing it with the students' school experiences in Catholic secondary schools which do not use this technology. Specifically, the objectives of the study are to: 
- investigate the different school experiences for students in the two types of secondary schools, due to either the presence or absence of the new mode of instruction;

- investigate the attitudes of students, their teachers and parents towards the "plasma" mode of instruction; and

- suggest possible improvements in the schools' situation for the best possible learning outcomes.

To attain the above objectives, the following research questions are set:

1. What are the school experiences of the Government secondary school students in relation to the introduction of the "plasma" from the point of view of the students themselves, their parents, and teachers?

2. What factors affect these school experiences compared to their experiences before the introduction of the "plasma"?

3. Is there any difference in the types of school experiences between students who are attending Government and Catholic secondary schools due to the introduction of "plasma" in the Government schools?

4. What are the implications of these school experiences for the students' learning?

\section{A brief description of the country}

Ethiopia is located in the northeast part of Africa, usually called the Horn of Africa. It embraces a complex variety of nations, nationalities and people and linguistic groups. Its people altogether speak over 100 different languages. Its area is 1.1 million square kilometres. According to the 2006 estimate, its population is about 77 million. English is the most widely spoken foreign language and is taught in all secondary schools. Amharic is the official language.

\section{Education}

Historical studies of education in Ethiopia indicate that the traditional education system of the country was religious oriented; and the two institutions that monopolised traditional education for centuries were the Orthodox Church and the Mosque (Teshome, 1979). In fact, church education in Ethiopia has pervaded the norms, values and culture of the existing society and it has been dominantly applicable until recently. The first modern school in Ethiopia was opened for the public in 1908. However, the school curriculum (the essence of the curriculum and the curriculum materials) was predominantly influenced by Western traditions.

The structure of the Ethiopian education system has been changed recently from $6+2$ $+4+$, to $4+4+2+2+$; that is, 8 years of primary education from year 1 to 8 , and subdivided into two cycles: First cycle (basic education) - from year 1 to 4 , and Second cycle (general education) - from year 5 to 8 ; and 4 years of secondary education that is, again, subdivided into two cycles: General secondary education for years 9 and 10, first cycle; and preparatory senior secondary education for years 11 and 12, second cycle (TGE, 1994). Tertiary and higher education is also provided at different levels.

\section{Ethiopian schools curriculum design}

In principle, the objective of the secondary school curriculum focuses at enabling students to solve real life problems and become independent, helpful citizens (TGE, 
1994). The curriculum, particularly for the secondary level of education, is designed at a national level. In fact, nowadays, the Government provided a certain degree of autonomy for the regions to design their own curricula for the primary level of education (year 1 to 8 ) based on some common frameworks. The regions are also allowed to use their own language as a medium of instruction for primary education.

However, the design of the primary school curriculum is decentralised only up to the regional level, and the individual Government schools do not design and implement their own curriculum at any level. The formulation of the country's education policy, the determination and supervision of the educational standards, the determination (design) of the curriculum of the secondary schools as well as the preparation of the national exams, lie solely on the hands of the Ministry of Education (MOE) at the national level (Derebessa, 1998:73). Hence, the Ethiopian secondary school curriculum is more centralised. This shows that Ethiopia is still following a top down tradition of curriculum design processes. However, Catholic schools have a little more autonomy than the Government schools in the above respect, though they are still using the same national curriculum.

The impact of such a curriculum and religious oriented school culture on the students to be studied, on their parents and teachers seems unquestionable. Its implication on this study is that the current students' school experiences may be affected by their school's determination to follow the national curriculum and the suggested methodology strictly.

\section{Research methodology}

This is a qualitative study as it is concerned with explaining the actual experiences of students in schools (Kumar, 1996). It involves a comparative research where it tries to relate the students' school experience in different types of secondary schools, that is, Government and Catholic. It uses an ethnographic approach that is designed within a qualitative research paradigm (e.g. Delamont, 2001; Pollner \& Emerson, 2001). This helped to obtain first hand information about the participants studied.

Interviews, observations and document analyses described below are the major data collection tools used in the paper. It is believed that more clarified responses (data) about the students' school experiences can be obtained by using a combination of different methods (e.g. Arksey \& Knight, 1999; Minichiello et al, 1997). Data was collected from April 2006 to September 2006. The main participants of the study are secondary school students, their parents and teachers. For this purpose, three secondary schools were selected, two Government schools (one from the capital and another from a village), and one Catholic school from the capital. A total of 21 participants were chosen for interviews, comprising nine students (three in each school), six of their teachers (two in each school) and six parents (two parents of two student participants in each school), selected using purposive and simple random sampling techniques. This sample size is considered to be sufficient for a paper which is part of a thesis conducted by a single researcher in order to carryout in depth interviewing (Minichiello et al, 1997). The students were chosen randomly from the three schools to give every student an equal chance of being selected (Galloway, 1997). Purposive sampling was employed to obtain parent and teacher participants who were the parents and teachers of the selected students so that triangulation of data is possible. 


\section{Semi-structured interviews}

Semi-structured interviews with open ended questions were employed (Arksey \& Knight, 1999). This type of qualitative data gathering technique helped to obtain more information from participants by involving each in a detailed conversation (ibid.). Interview schedules (Minichiello et al, 1997) were prepared for this purpose (see Appendix A) and interviews were recorded for later transcription. This allowed maximum attention to be given to the interviewee rather than concentrating on taking notes (Powney \& Watts, 1987). However, I also took notes while the interviews were underway and immediately after the interview sessions. Every effort was made to minimise the effect of using audio recording upon the interviewees' responses, and it was explained to the participants that the recorded interviews were to remain in the author's possession. The interviews were conducted in Amharic (the national language of Ethiopia) and translated to English. After transcribing of translations, an Ethiopian educator who had no knowledge of the participants listened to the audio recordings to check the accuracy of the author's translations.

\section{Observation}

Participant observation was used here to carefully observe everything the students performed and displayed inside and outside of the classroom in the three schools. An observation checklist was prepared for this purpose (see Appendix B) and three week periods of consecutive observations in each school were made to increase the reliability of the data. This method is considered as a core instrument of collecting data from the real scene, especially in ethnographic studies of this type (e.g. Garson, 2005; Delamont, 2001; Heyl, 2001). This is intended to help a researcher gain the "emic" or the "native's point of view" without imposing one's own conceptual framework (Garson, 2005). I recorded detailed field notes at this juncture. Participant observations and the use of filed notes are also recommended by Emerson, Fretz and Shaw (2001) for ethnographic researches of this kind. Jung and Boman (2003) used this method in a comparative study of disruptive behaviours in South Australian LOTE and mainstream primary school classrooms.

\section{Document analysis}

Curriculum documents, textbooks, teachers' lesson plans, students' notes, school timetables, and other school programs and documents were collected and analysed. Lincoln and Guba (1985) support the use of document analyses as these are readily available and stable sources of data. Garson (2005) also recommends gathering whatever site documents might be available in the research setting as data. Besides, pictures of different sites of the schools were taken to support the analysis.

\section{Method of data analysis}

After conducting the interview by using an audio recorder, the recorded responses and the filed notes taken by hand were transcribed. The first version of the transcription has contained almost all the information, including the details, given by the participants. I tried to take notes and remember the feeling and body language of the participants in order to not focus only on the spoken aspects of the interview when transcribing (Arksey \& Knight, 1999). Data reduction or condensing the data was carried out later (Kvale, 1996). Codes were used to signify themes drawn from the interviews and the observation (Strauss \& Corbin, 1998). This is what Kvale (1996) 
described as "meaning categorisation". My reflections and remarks were made at the margins of the transcription (Miles \& Huberman, 1994).

Each particular research question has several interview questions aimed at answering the basic questions. Attempts were made to identify and sort out similar patterns and themes of responses. Later, I condensed the meanings of the responses. Then, I structured the meanings of the displayed data through narratives (Kvale, 1996). Cortazzi (2001) supports the use of narrative analysis in ethnographic studies. Finally, constructs were developed from the identified patterns or themes of responses (Miles \& Huberman, 1994).

\title{
Results and discussion
}

All the students, their teachers and parents enumerated different types of school experiences that the students undertake in the Government and Catholic secondary schools. Experiences gained in the classroom at the time of the "plasma" transmissions in the Government schools are presented first below.

\section{School experiences for students in Government secondary schools}

One experience that is mentioned by eleven out of fourteen Government school participants as a positive effect of the newly introduced "plasma" model of teaching is the development of the students' English language listening skills. Three (out of four) teachers and four (out of six) students agreed that most of the students are now catching new words as a result of listening to them repeatedly from the "plasma" transmission. However, as these participants argued, this occurs at the expense of the other learning outcomes. That is, almost all the participants in the Government schools agreed that most of the students' time is spent in listening to the lectures of the classroom provided by the "plasma" instructor (see Figure 1). For instance, as one teacher said:

\begin{abstract}
...the education system currently is in danger. Specially, the majority of the students cannot follow and understand the lessons broadcasted through the Plasma. One of the main problems is language. Most of the students do not have the necessary English skill to listen and understand the live transmissions. It is also very fast, we cannot control it and the instructional time ends without the students understanding the subject matter. Since 35 out of the 45 minutes assigned for the period are spent on the live broadcast, how can I cater [for] the needs of the 90 to 95 students in a class with the remaining ten minutes? How can I carry out and encourage a teacher-students classroom interaction? This is just impossible with this condition. Besides, we are only there to control the students watch the TV and provide a five minutes introduction at the beginning and another five minutes summary at the end of the live plasma transmission. It is a chaos (Year 9 teacher).
\end{abstract}

The above idea, though expressed by a single teacher, was shared by almost all the student, parent and teacher participants from the three schools. The only exception is that two of the three teachers in the Catholic school did not report the case of the Government schools as severely as it is said by others. They instead condemn the administration of the "plasma" and agreed that the length of transmission (35 minutes in a single period) is too much.

When we look into the above responses in depth, there are two seemingly opposite ideas from the same participants; that is, on the one hand, they said that live 
transmission improves the listening skills of the students; and on the other hand, they said also that the students are spending their instructional time in listening. For a skill to develop, a certain period of time will usually be spent. However, here, the contexts of the responses were different. When the participants say, 'most of the students' time is spent in listening', they indicate the presence of many more equally important and key learning skills to be developed. They, for instance, mentioned the need to get time for student-teacher and student-student interactions so that the students' level of understanding of the contents will improve. In doing so, their communication skills, not only listening, but also speaking skills, and thereby their ability to think critically, have a better opportunity to develop.

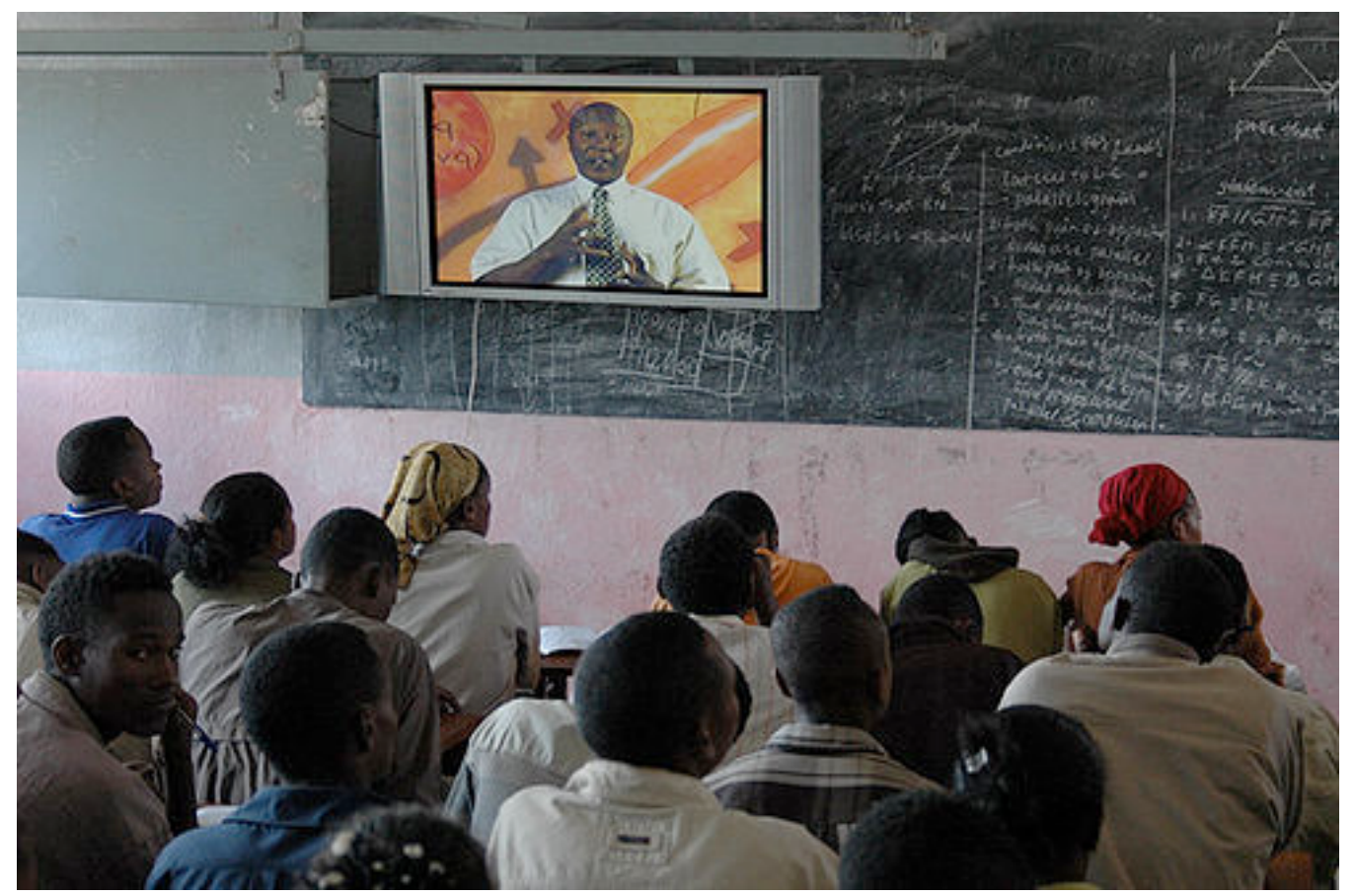

Figure 1: Live "plasma" transmission in a government school classroom Source: Heavens, 2005. Copyright Andrew Heavens of www.meskelsquare.com Reproduced by permission.

Whilst the participant quoted above said "since 35 out of the 45 minutes assigned for the period are spent on the live broadcast, how can I cater the needs of the 90 to 95 students in a class with the remaining ten minutes?... This is just impossible with this condition", he was not resisting completely the introduction of the "plasma" model of teaching, rather the way it is administered, that is, using a live transmission, and the amount of time allocated to it. His last sentences read as "besides, we are only there to control the students watch the TV and provide a five minutes introduction at the beginning and another five minutes summary at the end of the live plasma transmission. It is a chaos" clearly indicates a frustration about his role as a teacher and its adverse effect on students' learning. This idea is also supported by other research studies conducted by Tessema (2006) in an investigation into the contradictions, challenges, and chaos in Ethiopian education, by Hussien (2006) in a study of secondary schools in Ethiopia and the satellite television education, and by Lemma 
(2006). These studies claim that although the teachers were trained to plan their lessons, to involve students in active learning experiences, to assess, etc, their role is now reduced to lesson introduction, lesson summarising and as TV operators due to the "plasma" instruction. The teachers are now simply "executioners of what others planned or wanted to happen in the classroom" (Tessema, 2006:6) and this is what Apple (2000) characterised as "deskilling".

In the interviews, language was one of the major problems reported repeatedly by all of the fourteen participants in the Government schools. This is also reported by Lemma's classroom observation in one secondary school (Lemma, 2006). It seems appropriate also to argue that the students could understand a learning material better if they had a good skills in English before the language became a medium of instruction. Most of the participants' comments on the language also rest on this idea. They challenged the Government by saying students could get enough exposure to the language at Year 7 and Year 8. In this connection, one anonymous person commented about the current classroom situation:

... students in the different regions of the country are not thought [sic] the different subjects in English (except one period of English) till 9th grade and take the school leaving examination at 10th grade IN ENGLISH. They were struggling even with the actual teachers, and I cannot imagine how hard it is for them to learn from an English speaking machine that will not interact with them. It is a mess... (Anonymous in Heavens, 2005).

An overseas journalist who visited the southern part of Ethiopia in 2005 observed a classroom and described the "plasma" transmission as "the shock of the new" (Heavens, 2005). He noted that “... students were all taking their lessons from a professor speaking through a state-of-the-art Samsung Plasma video screen that would be way beyond the budget of many schools in the UK". He discussed the transmission with a headteacher who expressed the view that "... students had found it hard to keep up with the English used by the Addis-based teachers" (Heavens, 2005). Nevertheless, the headteacher added that they "soon got used to it."

In addition to the language problem, the speed of the transmission was another major problem mentioned by thirteen participants. Classroom observations also proved this assertion and it was supported by Lemma (2006). A comment form a techer quoted above, "It (the transmission) is also very fast, we cannot control it and the instructional time ends without the students understanding the subject matter" shows the nonrepeatable and 'non-rewindable' nature of such kind of live transmissions, unless they are copied for later use, which is practically impossible in the cases of these schools because they have no equipment to do so. Neither the teacher nor the students have control over the transmissions. It is pre-programmed so that it does not cater the needs and pace of the students. This kind of education system requires the students to adjust themselves to the technology which replaces the teacher. In relation to this, other teacher educators (e.g. Tessema, 2006; Hussien, 2006) have commented on the newly introduced transmission and said it is a "one size fits all" approach to education and thus does not cater for the diversity of the students.

In relation to the problems of the "plasma" transmission, one student requested help through the Internet by addressing her problems as:

How dose [sic] one get a CD copy of the plasma education? I would like to study at home in my own computer. At school the English in plasma is not good for me. It is 
too fast and too short, the supporting materials are not easily available particularly for those of us outside Addis [the capital]. My teachers are not sometimes sure of the subject maybe because of the English like myself. Most students are not happy with the plasma. We would like to get copy of the CDs so we could study at our own time. Please help us (Feven in Heavens, 2005).

Although this would not work for the great majority of the students who do not have computer or television at home, all the Government and Catholic school teacher participants believed that CDs/DVDs could be distributed to schools for later use. Another participant from my study also explained that

I taught in this school for seven years, I know the students well before the introduction of the plasma. Although the students' interest is still high, their results have become worse since they began to learn through the plasma. I am not sure even whether they understand $50 \%$ of the contents in the transmission. Because of the language problem and the high speed of the transmission, the students always complain that they have not understood the lessons. More tutorials and teacher-student interactions are needed. Besides, we sometimes cannot attend the live transmission because of either light or technical problems, and hence we miss those lessons for good (Year 11 teacher).

The problems illustrated in the quotes above were mentioned repeatedly by five (out of six) students in the Government schools. These participants compared their previous classroom performance with the current one and labelled the latter as very poor. All the students agreed that they would understand the lessons better if they were provided more time with their teachers in the classroom.

On the other hand, the Government gave justifications for introducing "plasma" program as "In the globalised world, information and communication technology is vital, (and hence), installation of satellite receiving devices known as plasma display panels (PDPs) in every classroom at secondary level is necessary" (FDRE, 2004:8). The Government also explained specific reasons for the need of the "plasma" mode of instruction as "to present abstract concepts in a simplified manner; to transmit uniform education to many students found in different places at the same time; to enable students to have access to model and competent teachers; to demonstrate laboratory equipment found in one place (classroom) to other learning classrooms" (FDRE, 2004: 8-9).

The Government's objectives in introducing the "plasma" mode of instruction are quite attractive on paper. TV was also used for many years in Ethiopia in some towns for non-formal education and to augment the formal traditional instruction (Tilson \& Bekel, 2000). However, it is essential to examine the current exclusively "plasma" based classroom situations carefully from different perspectives as follows.

\section{A pedagogical perspective}

Pedagogically, it is quite right and sometimes necessary to use teaching aids like "plasma" in the classroom so that abstract contents can be more clarified through it. Very expensive experiments which cannot be conducted in each classroom can also be demonstrated through such a mechanism. This is especially helpful for remote schools where they may have problems of obtaining well qualified teachers, lab equipment and the like (Evans, Stacey \& Tregenza, 2003), as it is a case of many secondary schools in Ethiopia. This is also well highlighted in the Government's justifications above. In addition, when students have no opportunity to visit some places which are important 
for their lessons, TV can be a complement. Besides, since students use at least two of their senses in the "plasma" programs, seeing and listening, their attention span as well as the potential to memorise the contents will increase, compared to only attending a teacher's lecture in a traditional classroom.

The point here is, at any circumstance, the "plasma" cannot be a substitute for a teacher in the classroom as it is occurring now in Ethiopia. Nothing can substitute the live interaction between the teacher and the students as well as among the students as learning is also social in character. Much literature supports the theory that interactions among students and between the students and teachers enhance the students' opportunity for learning to think critically in the traditional classrooms (Brookfield, 1987). Otherwise, the students' role will be restricted only to listening which may, at most, result in rote and passive learning. This legitimates the practice of what Freire (1993) described as the "banking" concept of education which denies "dialogical" relation among the learners and between the learners and the teacher. If, at least, it was an interactive TV in which students can also get the access to watch while other students interact in the classroom in the same topic, and had additional time to discuss with their teachers and their fellow students, it would be preferable. There are findings which support the idea that using interactive TV in teaching is as effective as face to face instruction with regard to acquisition of critical thinking skills which includes reasoning, solving problems, creating and evaluating knowledge (Huff, 2000).

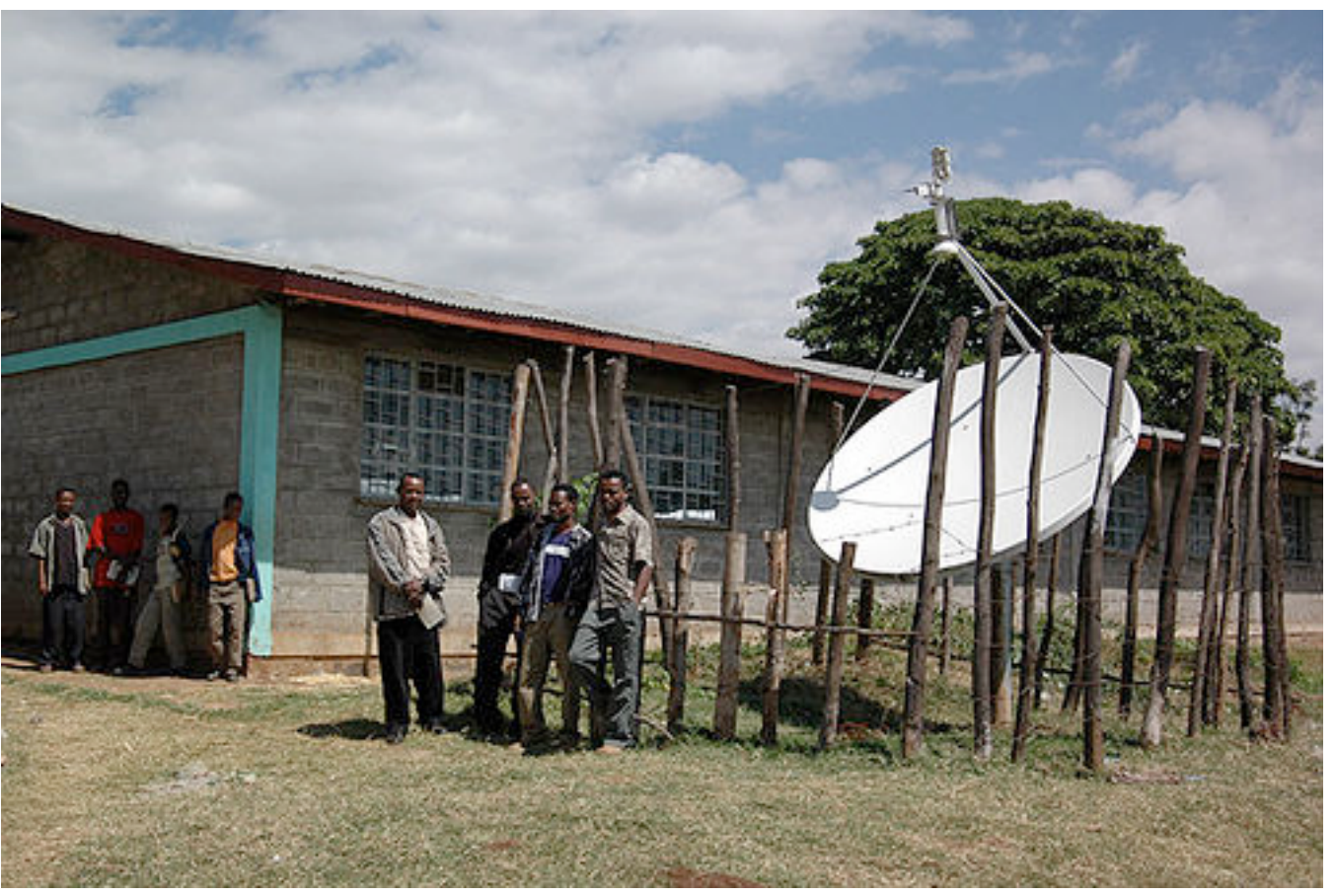

Figure 2: "Plasma" TV satellite installation in a school Source: Heavens, 2005. Copyright Andrew Heavens of www.meskelsquare.com. Reproduced by permission. 


\section{A cultural perspective}

As explained in the background section, both Church and Islamic education systems were aiming at producing an obedient and submissive adult who follows and practices the rules and laws provided by God (Allah) and by his elders. This type of education system was not placing a priority on producing a creative and analytical person. The New Education and Training Policy (TGE, 1994) was hence targeted to minimise these problems. One of its objectives was to encourage the creative power of the students and to enable the students solve their own problems. Now, the question is how can we produce creative citizens by restricting them only to listening to a nationally designed lesson? Can students, who simply listen and watch 35 minutes of the 45 from the Plasma transmission and the remaining 10 minutes from their teachers, develop their creativity?

\section{An economic perspective}

Ethiopia is a very poor country and according to a 2004 US government report, its per capita income is $\$ 116$. However, the state is now spending $10 \%$ of its total budget for only the "plasma" transmission (See Figure 2). There are many educators, students, teachers and parents who share the view that if the state spends this money to train more qualified teachers, reduce the class size, purchase books and essential equipment for labs, the quality of education will be better than its current status.

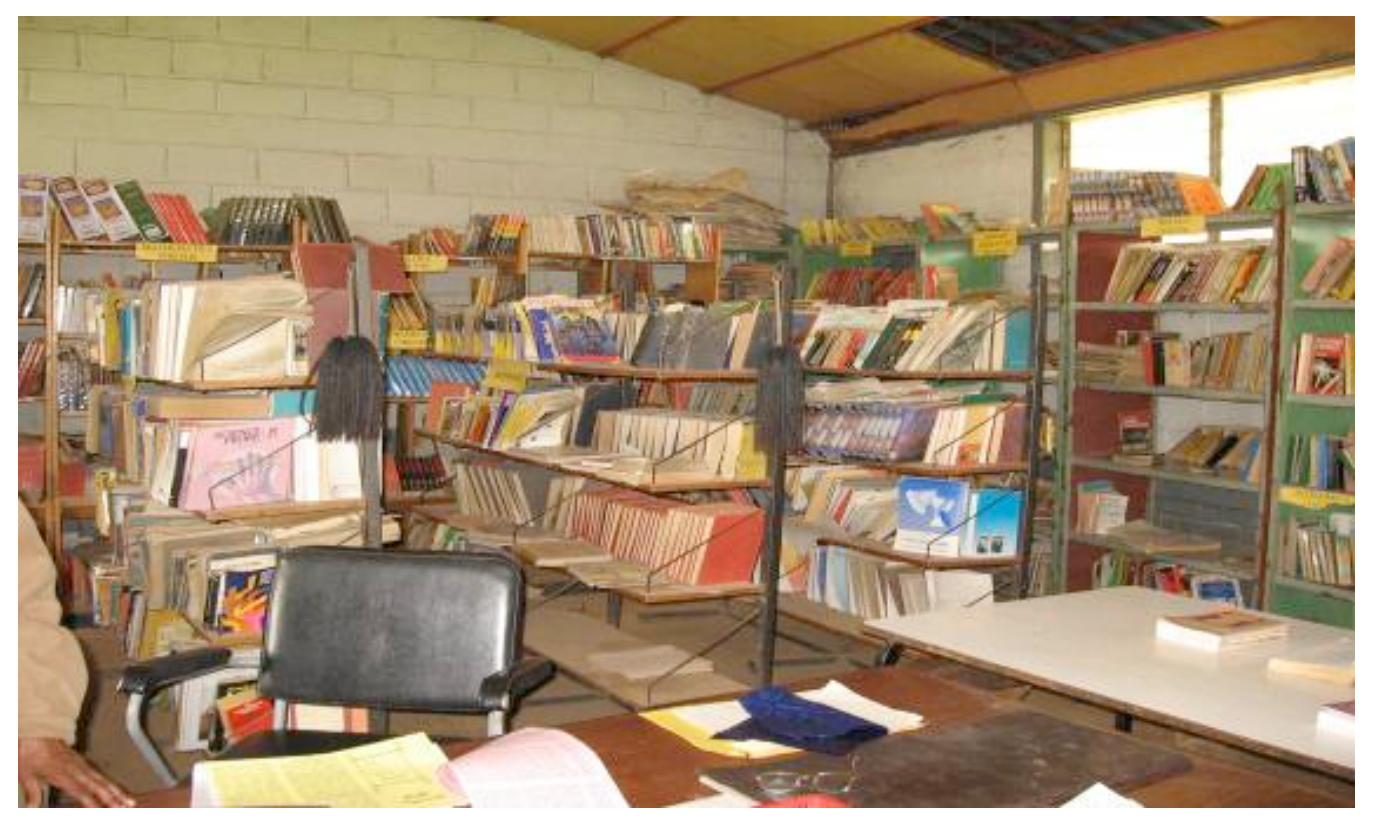

Figure 3: A library in one of the government schools Source: Author. Photo taken during data collection, 2006.

It is suggestive from Figure 2 that the state spends too much money upon installing a modern technology whilst not delivering some essentials for students. Figure 3 and Figure 4 illustrate the severe situations for libraries and classrooms in the Government schools. I have known the school and its library (Figures 3 and 4) for twenty years, and the chairs, the space available, the old books and everything in it are almost the same. 
On the other hand, the number of students has increased. Imagine, three and sometimes four students sitting at one small desk. The question now is which one has to be given priority? For a developing country with poor infrastructure for technology (e.g. power failure several times during my observations, as reported by teachers interviewed, and by Lemma, 2006), taking the plasma transmission as a sole method of teaching is at least a risk by itself. There were many days in which this technology was not working and hence there was no instruction in many schools. These days, the state itself has accepted the truth that the quality of education in Ethiopia is deteriorating and it is beginning to study the causes (ETV, 2006).

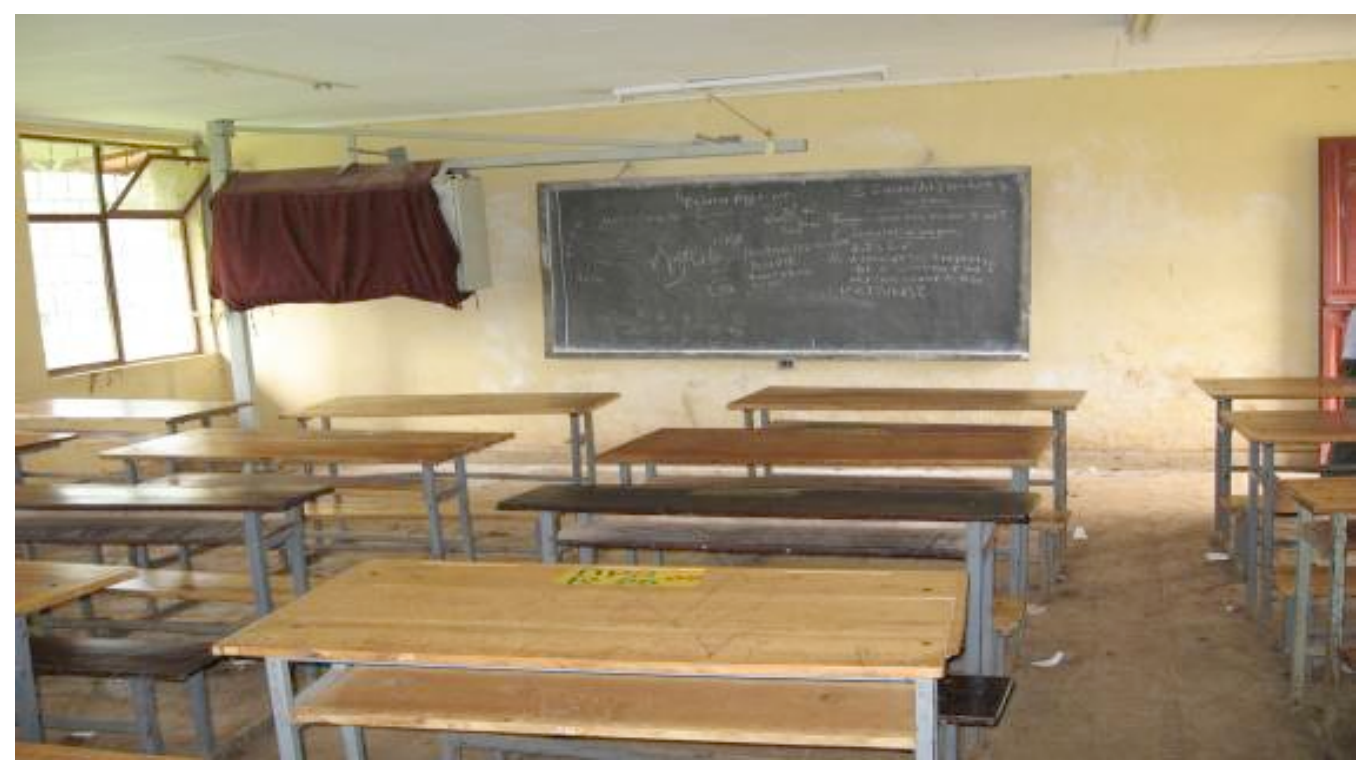

Figure 4: A typical classroom in a government school

Source: Author. Photo taken during data collection, 2006.

\section{A political perspective}

If we consider the current educational system of Ethiopia in a political context, there may be many people who believe that the state is totally controlling the education system only to maintain its power. Because the state encountered a severe problem and political crisis from the opposition parties and the masses, and several mobs and demonstrations were held in the schools against the state, the current introduction of the obligatory live "plasma" transmission to the schools is designed to reduce and thereby obstruct the students' and teachers' attention as well as potential to meet, discuss and possibly revolt against it. A university lecturer who studied the current education system of Ethiopia wrote about a mismatch between the state's discourse and practices in its introduction of the mandatory live "plasma" transmission into every Government school. He stated the "constrictions and convulsion between discourse and practice as a struggle and legitimated attempt to use education as a vehicle for controlling the hearts and minds of citizens" (Tessema, 2006:2). A similar study conducted by Hussien (2006) characterised such an education system as "a digitalised perpetuation of control on human mind". 
In fact, 18 of the total 21 participants condemned the state for introducing "plasma" transmission as the sole source of students' learning. 13 of these participants believe that the state did so deliberately, to give a special advantage to the children of the rich (most of whom are children of the ruling class) who are very small in number, at the expense of the children of the poor (the majority, estimated as over $90 \%$ of the total students in many classrooms). According to these participants, the children of the rich have been watching TV throughout their entire lives; they have their own private tutors and get any kind of language and academic help needed. These students can understand the "plasma" transmission easily, get good grades in the national examination which is "norm referenced" in character, and enter university actually without any competition. On the contrary, the remaining students, the majority, the children of the poor who had no chance to get their lunch, let alone a TV in their homes, will be failures and end up unemployed. Above all, the majority of the children of the rich are attending in Catholic schools which incur outstanding fees. These schools are not using "plasma" transmissions. Hence, the administration of the "plasma" instruction is seen as widening the educational status gab between the poor and the rich.

\section{School experiences for students in Catholic secondary schools}

A student of a Catholic school explained her school experience in a different way:

I joined this school by my choice because I heard its reputation from my elder sister. There is more teacher help and project work. Our assignments are corrected on time. There is also great interaction with other students... I like Biology most because the teacher is very good in explaining the topics; he presents the lessons to the simplest possible way and I like the subject. Other teachers also make their best efforts to explain contents and initiate us to ask and answer questions, to participate in the classroom (Year 9 student).

Similarly, a teacher in the same Catholic school explained his view as:

Students like assignments and project works but do not want to get bored by a similar method of teaching. They need and like more initiations and personal follow-up. Students need the methodology to be attractive. And, our lessons are more of studentcentred. We discuss about the lessons in the classroom, I give assignments and project works, and I always correct students' papers. Students have also good skills of English language (Year 9 teacher).

The responses above illustrate that the school experiences of the students in the Catholic school are quite different. Here, students are provided with different project works and assignments, and the teachers generally use a variety of methodologies as well as check and make corrections of the students' work. There is also more studentteacher interactions in the classroom. This has boosted students' positive attitude towards their lessons - as the above student participant clearly put it. The classroom observations also confirmed the above responses.

In this school, students read some books while doing the assignments and learn the various subjects accordingly from year 9 to 12. Students mentioned that they read textbooks in the different subjects, additional reference materials and fictions in the school because their instructional time is not crowded by a "plasma" transmission. As the interviews indicated, almost all students in the Catholic school obtained some concepts and ideas in their reading; try to understand them; write as well as explain their understanding in their own words in English classes, for instance. While making 
a speech on a topic, they learn some rules such as eye contact and get assessed with it, as two of the participants depicted it in this same Catholic school. In their reading of the curriculum materials such as the textbooks, students said that they analysed, synthesised and evaluated the materials. That is, not only do they try to understand what they read, but also they assess the value of the material. Besides, in some classes, for example English, they write essays and do project work. In some others, for example Mathematics and Physics, they deal with real problems.

Though two of the three teachers commented on the lack of connection between most of the contents and the students' real life, all the students in this Catholic school said that they have some "good lessons" (e.g. in Physics) which are directly connected to their real life and they are practising to solve those problems which they face in the real world outside the school. This is consistent with what Cauley, Certo and Chafin (2003) called "authentic curriculum and class work". That is, the extent to which the students actually feel, or touch, or do some kind of learning directly related to their life problems, while interacting with the curriculum materials.

Observations of the students' school experiences inside and outside the classrooms also indicated that students of the Catholic school spend most of their time through interaction with the teacher and their fellow students - unlike the case in the Government schools. For instance, students of the Catholic school were observed outside the classroom discussing an issue raised in their English class (see Figure 5).

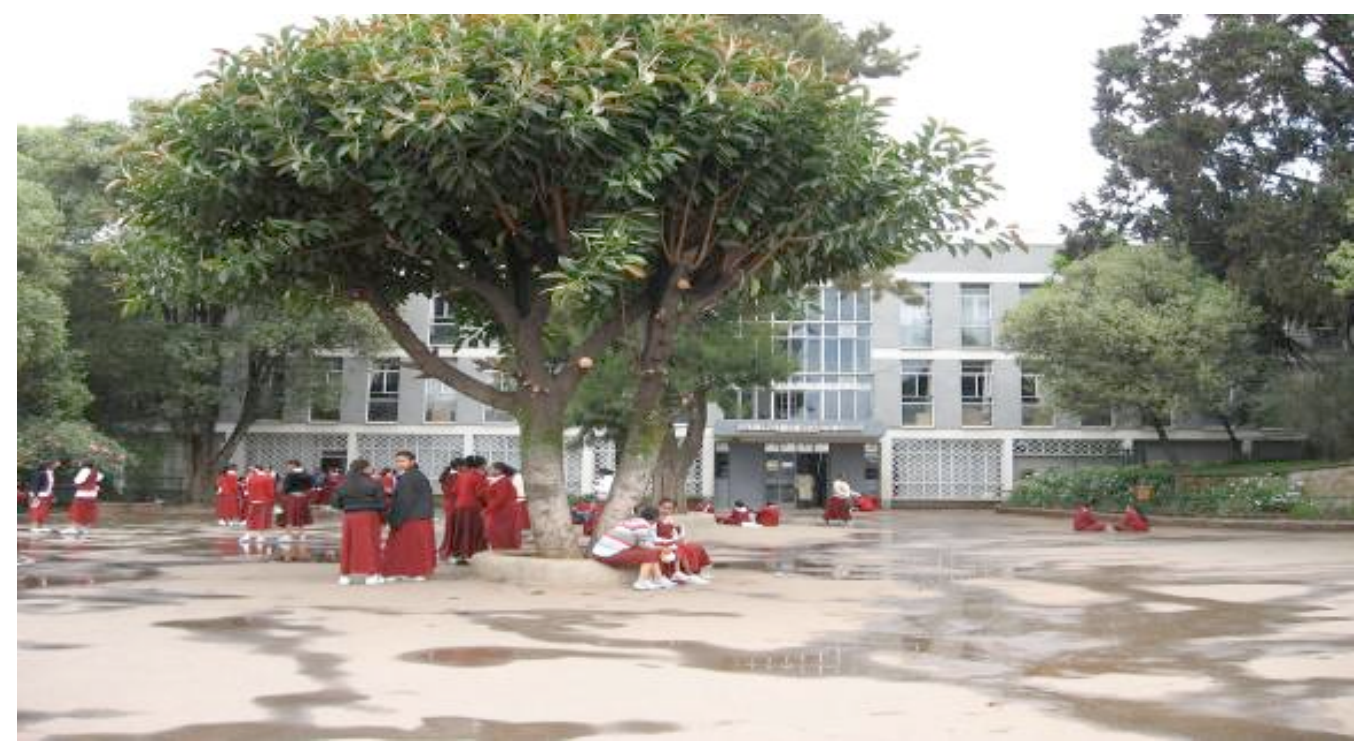

Figure 5: Some students in teams discussing their last lesson in a Catholic school Source: Author. Photo taken during data collection, 2006.

\section{Conclusions and recommendations}

Based on the data collected and the discussions undertaken, the students' classroom activities and their school experiences in Government and Catholic schools are quite different. Students in the Government schools are found spending the majority of their instructional time listening to the "plasma" transmission without making any live 
interaction. They are passive and dissatisfied with the current mode of instruction. The major factors associated with their dissatisfaction are the high level of English language skills assumed by the "plasma" teacher, the speed of the presentations which creates difficulties for conceptual understanding, and the lack of class time for the students to discuss with their teachers and fellow students. On the other hand, students in the Catholic school are observed as more comfortable with their school's mode of instruction compared with students in the Government schools. In the Catholic school, students have enough time in the classroom for discussions about what they have learned. They are encouraged by the teacher to ask and answer questions, and to participate in class discussions. They also get continuous feedback from their teachers. The implication of such school experience is clear. Students of the Catholic school will be more positive towards their learning than the other students. Developing the skills of interaction in the classroom has also a positive effect on their future life including in any university study. There is also a greater possibility for the students of the Government schools to uphold the shy, obedient, submissive and passive character of their past, endowed from their parents as a result of the traditional education systems, that is, the church and the Islamic education.

The following recommendations are proposed, based on the data collected:

- The state shall re-examine its mandatory "plasma" transmission as the only mode of instruction. It should rather be used as a supplement to a learner centred classroom so that students and teachers can make a choice in their learning.

- There is no suggestion made by the participants which says that the state should abandon the transmission. But as the participants in both schools recommended, the transmission shall be sent in CDs/DVDs to each school so that they can be helpful as teaching aids rather than seen as a burden imposed by the state.

- The teachers and students should get more time in the classrooms of the government schools so that they can discuss the learning materials in depth and thereby develop different skills such as interaction skills.

- It is felt strongly by the majority of the participants that the quality of Ethiopian education would be improved if the money spent in the live "plasma" transmissions is used for training teachers and reducing other crucial resources shortages such as libraries and laboratories.

\section{Acknowledgements}

The author and AJET are grateful to Andew Heavens of www.meskelsquare.com for permission to reproduce Figures 1 and 2.

\section{References}

Apple, M. (2000). Official knowledge: Democratic education in conservative age. New York: Routledge.

Arksey, H. \& Knight, P. (1999). Interviewing for social scientists. London: SAGE.

Berumen, G. \& Xavier, F. (2004). The high school experiences of Chicano students with gang affiliation in a Los Angeles public school: A study to inform pedagogical and curricular intervention strategies. USA: Harvard University.

Brookfield, S. (1987). Developing critical thinkers. San Francisco: Jossey-Bass. 
Cauley, K. M., Certo, J. L. \& Chafin, C. (2003). Students' perspectives on their high school experience. Adolescence, 38(152), 705-724. [verified 4 Feb 2008] http: / / findarticles.com/p/articles/mi_m2248/is_152_38/ai_n6005505/pg_1

Cortazzi, M. (2001). Narrative analysis in ethnography. In P. Atkinson et al (Eds.). Handbook of ethnography. London: SAGE Publications.

Delamont, S. (2001). Fieldwork in educational settings: Methods, pitfalls and perspectives. London: RoutledgeFalmer.

Derebessa, D. (1998). Planning education under a decentralized system. In A. Amare et al (Eds.). Quality education in Ethiopia: Visions for the 21st century. Addis Ababa University: Institute of Educational Research.

Emerson, R., Fretz, R. \& Shaw, L. (2001). Participant observation and fieldnotes. In P. Atkinson, et al (Eds.). Handbook of ethnography. London: SAGE Publications.

ETV (Ethiopian Television Broadcasting Service) (2006). Quality of education. Official speech of the Ministry of Education in consecutive TV transmissions in August. Addis Ababa.

Evans, T., Stacey, E. \& Tregenza, K. (2003). Interactive television in schools: An Australian study of the tensions of educational technology and change. International Review of Research in Open and Distance Learning, 2(1). http:/ / www.irrodl.org/index.php/irrodl/article/viewFile/31/83

FDRE (The Federal Democratic Republic of Ethiopia). (2004). Development of education in Ethiopia. A Report to the UNESCO Forty-Seventh Session of the International Conference on Education, 8-11 September 2004. Switzerland: Geneva.

Freire, P. (1993). Pedagogy of the oppressed. New York: The Continuum Publishing Company.

Galloway, A. (1997). Sampling. [viewed 22 Mar 2006, verified 4 Feb 2008] http:/ / www.tardis.ed.ac.uk/ kate/ qmcweb/scont.htm

Garson, D. (2005). Ethnographic research. [viewed 22 May2006, verified 4 Feb 2008] http: / / www2.chass.ncsu.edu/garson/PA765/ ethno.htm

Harwick, C. (2000). Student voices: Reflections on the continuation high school experience. Azusa: Azusa Pacific University.

Heavens, A. (2005). The shock of the new. [viewed 25 Oct 2006, verified 4 Feb 2008] http: / / www.meskelsquare.com/archives/2005/01/the_shock_of_th.html

Heyl, B. (2001). Ethnographic interviewing. In P. Atkinson et al (Eds.). Handbook of ethnography. London: SAGE Publications.

Huff, M. (2000). A comparison study of live instruction versus interactive television for teaching MSW students critical thinking skills. Research on Social Work Practice, 10(4).

Hussien, J. (2006). Locating the value conflicts between the rhetoric and practices of the public and teacher education in Ethiopia within the hegemony of the global neo-liberalism and seeking the alternative in critical pedagogy. Journal for Critical Education Policy Studies, 4(2). http: / / www.jceps.com/index.php?pageID $=$ article\&articleID $=80$

Jung, J. \& Boman, P. (2003). Comparison of disruptive behaviours in South Australian LOTE and mainstream primary school classrooms. Journal of Educational Enquiry, 4(2).

Kumar, R. (1996). Research methodology: A step-by-step guide for beginners. Melbourne: Addison Wesley Longman Australia Pty Ltd.

Kvale, S. (1996). Interviews: An introduction to qualitative research interviewing. Thousand Oaks: SAGE Publications.

Lemma, B. (2006). Plasma television teachers - When a different reality takes over African education. In L. Dahlström \& J. Mannberg (Eds), Critical educational visions and practices in neo-liberal times, 71-88. Umeå University: Global South Network Publisher. http: / / alfa.ped.umu.se/projekt/globalsouthnetwork/_pages_/docs /Critical\%20 Educational\%20Visions $\% 20$ and $\% 20$ Practices.pdf 
Lincoln, Y. \& Guba, E. (1985). Naturalistic inquiry. Beverly Hills, CA: Sage Publications.

Miles, M. \& Huberman, A. (1994). An expanded sourcebook: Qualitative data analysis (2nd ed.). Thousand Oaks: Sage Publications, Inc.

Minichiello, V. et al. (1997). In-depth interviewing: Principles, techniques, analysis. Melbourne: Addison Wesley Longman Australia Pty Ltd.

Pollner, M. \& Emerson, R. (2001). Ethnomethodology and ethnography. In P. Atkinson et al (Eds.), Handbook of ethnography. London: SAGE Publications.

Powney, J. \& Watts, M. (1987). Interviewing in educational research. London: Routledge \& Kegan Paul Ltd.

Richardson, V. (Ed.) (2001). Handbook of research on teaching (4th ed.). Washington, DC: AERA.

Shields, E. (2000). The new Americans: A qualitative study of the school experiences of three high school students from different continents. NY: New York University.

Strauss, A. \& Corbin, J. (1998). Basics of qualitative research: Techniques and procedures for developing grounded theory. Thousand Oaks: SAGE Publications, Inc.

Teshome, W. (1979). Education in Ethiopia: Prospect and retrospect. Rendale: Wiley Canada.

Tessema, K. (2006). Contradictions, challenges, and chaos in Ethiopian teacher education. Journal for Critical Education Policy Studies, 4(1). http:/ / www.jceps.com/?pageID=article\&articleID=62

TGE / Transitional Government of Ethiopia/ (MOE) (1994). Education and training policy. Addis Ababa: EMPDA.

Tilson, T. \& Bekele, D. (2000). Ethiopia: Educational radio and television. TeckKnowLogia, 2(3) (May/June). [viewed 31 Dec 2007, verified 4 Feb 2008] http:/ / www.techknowlogia.org/TKL _active_pages2 /Currentarticles / main.asp?IssueNumber=5\&FileType=HTML\&ArticleID=121

University of Kansas (2002). Classroom checklist for teachers. [viewed 25 Oct 2006, verified 4 Feb 2008] http: / / www.circleofinclusion.org/english/guidelines/modulefour/physical/k.html

\section{Appendix A}

\section{Interview questions (for students/ teachers/ parents)}

Part A. Main data: Questions related to the students' school experience

1. Tell me about your/your students' / your child's secondary school experience?

1.1 What was it like in the best classrooms?

1.2 Your/your students' / your child's school experience of least interest?

1.3 How did you/your students/your child choose the school which you(s/he) is attending now?

2. Specific questions related to the curricular practices:

2.1 What do you think is important to learn for you/your students/your child?

2.2 How useful is what you/your students / your child are learning (for instance, for future career?)

2.3 Tell me how easy or difficult the various subjects are for you/your students / your child?

3. Specific questions related to the pedagogical practices:

3.1 Tell me the class that you/your students/your child feel good and understand the subject better?

3.2 Tell me the best things that initiate you/your students / your child to learn a concept/idea?

3.3 In what way do you think is the school expects you/your students / your child to learn in the classroom?

3.4 Do the school activities meet your/your students' / your child's needs?

3.5 What is your opinion about the plasma mode of instruction?

3.6 What are the strengths of the plasma mode of instruction?

3.7 What are its weaknesses? 
3.8 What are the similarities and/or differences with your/your students' / your child's previous learning experience without the plasma; that is, the face to face mode of learning?

3.9 Which mode of instruction do you think is better and why?

3.10 How often do you/your students/your child participate in class discussions?

Part B. General questions:

1. Tell me about how far you/your students/your child enjoy learning at your school?

2. How can school be improved so that you/your students/your child learn better?

3. How is the school facility?

4. How do you rate your self/your students/your child in relation to the classroom learning and other students in the class?

Part C. Background/demographic data (students)

1. How old are you?

2. What grade are you in?

3. What subjects are you studying?

Part D. Background/demographic data (teachers/parents)

1. How many secondary school students/children do you teach in a class (do you have)?

2. How old is/are s/he/they?

3. For how many terms/semesters / years have you taught her/him? (Teachers)

4. In which grade level do you teach now (are they now)?

5. What subject do you teach? (Teachers)

Any other experiences, thoughts, or feelings you would like to add?

Thank you indeed for your time

\section{Appendix B}

\section{Classroom observation checklist}

This checklist (adapted from University of Kansas, 2002) guides the investigator to examine the routines of the classroom and thereby observe the students' classroom activities in the school.

School:

Teacher:

Subject:

Date:

Session:

Length of class session:

Number of days per week:

Number of students in class:

\section{Physical features}

1. Is the lighting acceptable?

2. Is there ample room for the number of people present?

3. Are learning materials (e.g. textbooks, pen) accessible and useable to the students?

4. Are other resources (e.g. library, computer, other equipment like gown in labs) accessible and useable to the students?

5. Are work and play areas separated to minimise distractions?

6. Is there a "private place" in the classroom where students may go if they feel overstimulated?

7. Is the plasma TV located in a position convenient for every student? 


\section{Seating routines}

1. Do students ever sit as a group?

2. Do students ever sit on individual spaces in chairs?

3. Do students at any time during the day sit in assigned seats?

4. Do they use a different seating arrangement to attend the plasma instruction?

\section{Go with the flow}

1. Are the students positioned so that they can see and participate in what is going on?

2. Are the students positioned so that classmates and teacher may easily interact with them (e.g. without teacher between a student and his/her classmates, no student isolated from classmates)?

\section{Acting cool}

1. Are the students actively involved in class activities (e.g. asks or responds to questions, plays a role in group activities)?

2. Do students interrupt the plasma transmission and ask the teacher when they do not understand the instruction?

3. Is assistance provided for the students by classroom teachers?

4. Does the teacher interrupt the plasma transmission when $\mathrm{s} /$ he feels to explain unclear lessons?

\section{Talking straight}

1. Do teachers (e.g. classroom teachers, support staff) provide the same type of feedback (e.g. praise, discipline) for each student?

2. Do teachers have good relationship with students?

3. Was the teacher's introduction at the beginning of the plasma instruction focused on explaining the succeeding lesson?

4. Was the teacher's summary at the end of the plasma instruction good enough to clarify the lessons?

\section{Classroom interaction (with and without the plasma instruction)}

1. Is there any time when children are allowed to work cooperatively?

2. Are social interactions encouraged?

3. Does the teacher find time for frequent personal comments to individual children during the plasma instruction?

4. Does the plasma transmission provide appropriate time to students to get help from classroom teachers?

5. How long are children expected to listen and converse in a large group setting?

6. Does the teacher use appropriate rate of presentation?

7. Is the students' attention span accommodated?

8. Does the teacher allow the student sufficient practice?

9. Are transitions flow smoothly without disruption?

10. Does the teacher encourage brief interactions among students?

11. Does the teacher arrange activities to allow for choice making?

12. Does the teacher use materials and activities within setting to meet students' needs?

13. Were most students happy in their facial expressions and gestures whilst attending the plasma instruction?

14. Was there any disruption during the live plasma transmission?

15. Other things observed during and without plasma transmission?

Getnet Demissie Bitew, Faculty of Education

The University of Melbourne, Victoria 3010, Australia

Email: getnetdb@yahoo.com or g.bitew@pgrad.unimelb.edu.au 